\title{
Review \\ Plant Dehydrins: Expression, Regulatory Networks, and Protective Roles in Plants Challenged by Abiotic Stress
}

\author{
Zhenping Sun, Shiyuan Li, Wenyu Chen, Jieqiong Zhang, Lixiao Zhang, Wei Sun * and Zenglan Wang *
}

check for

updates

Citation: Sun, Z.; Li, S.; Chen, W.; Zhang, J.; Zhang, L.; Sun, W.; Wang, Z. Plant Dehydrins: Expression,

Regulatory Networks, and Protective Roles in Plants Challenged by Abiotic Stress. Int. J. Mol. Sci. 2021, 22, 12619. https://doi.org/10.3390/ijms 222312619

Academic Editor: Abir U. Igamberdiev

Received: 27 October 2021

Accepted: 20 November 2021

Published: 23 November 2021

Publisher's Note: MDPI stays neutral with regard to jurisdictional claims in published maps and institutional affiliations.

Copyright: (c) 2021 by the authors. Licensee MDPI, Basel, Switzerland. This article is an open access article distributed under the terms and conditions of the Creative Commons Attribution (CC BY) license (https:/ / creativecommons.org/licenses/by/ $4.0 /)$.
Shandong Provincial Key Laboratory of Plant Stress Research, College of Life Science, Shandong Normal University, Jinan 250014, China; zhenpingsun0625@163.com (Z.S.); echosemail@163.com (S.L.); yuuuu_ccc1996@163.com (W.C.); zjq210306@163.com (J.Z.); LixiaoZhang0125@163.com (L.Z.)

* Correspondence: sunwei@sdnu.edu.cn (W.S.); wangzl@sdnu.edu.cn (Z.W.); Tel.: +86-137-9103-3469 (W.S.); $+86-155-8998-2165$ (Z.W.)

\begin{abstract}
Dehydrins, also known as Group II late embryogenesis abundant (LEA) proteins, are classic intrinsically disordered proteins, which have high hydrophilicity. A wide range of hostile environmental conditions including low temperature, drought, and high salinity stimulate dehydrin expression. Numerous studies have furnished evidence for the protective role played by dehydrins in plants exposed to abiotic stress. Furthermore, dehydrins play important roles in seed maturation and plant stress tolerance. Hence, dehydrins might also protect plasma membranes and proteins and stabilize DNA conformations. In the present review, we discuss the regulatory networks of dehydrin gene expression including the abscisic acid (ABA), mitogen-activated protein (MAP) kinase cascade, and $\mathrm{Ca}^{2+}$ signaling pathways. Crosstalk among these molecules and pathways may form a complex, diverse regulatory network, which may be implicated in regulating the same dehydrin.
\end{abstract}

Keywords: abiotic stress response; abscisic acid; calcium ion; dehydrin; mitogen-activated protein kinase

\section{Introduction}

Hostile environmental conditions such as high salinity, drought, and low temperature threaten plant growth and development and lower crop yield. Faced with stress, immobile plants have evolved complex regulatory mechanisms to adapt to or resist stress over a long period of natural selection. Thus, the self-protection mechanisms of plants have been investigated to improve plant abiotic stress resistance [1].

Abiotic stress can cause the accumulation of reactive oxygen species (ROS) which damage the structure of cell membranes and affect the functions of proteins and nucleic acids. In order to alleviate reactive oxygen species damage, plants have evolved natural antioxidant systems, enzymatic and non-enzymatic antioxidants. Diversiform antioxidant enzyme of plants, such as super-oxide dismutase (SOD) and ascorbate peroxidase (APX), have been reported to get rid of the ROS in abiotic stress response [2]. Non-enzymatic antioxidants mainly are organic compounds such as active peptides, vitamin E, vitamin C, polyphenols and anthocyanins. For example, rubiscolin-6, an opioid peptide of Rubisco that has the function of fixing $\mathrm{CO}_{2}$ in plant photosynthesis [3,4], serves as a radical scavenger [5]. Under drought treatment, the underground tissues of soybean express higher concentrations of vitamin $\mathrm{E}$ which protects the membrane from peroxidation [6]. Here, we will introduce a class of LEA protein family members-dehydrins, which also exhibit anti-oxidant functions.

Late embryogenesis abundant (LEA) proteins were initially detected in the late stages of seed maturation and were later found in seedlings, roots, stems, and other plant organs as well. Studies have shown that LEAs are implicated in plant growth, development, and stress response [7,8]. Dehydrins are Group II LEA proteins that play vital roles in establishing and maintaining plant stress tolerance. Several dehydrins, including RD29A, RD29B, and RAB18, show dynamic changes in their expression in response to plant abiotic 
stress; these changes are indicators of plant abiotic stress tolerance. The recent discovery of interactions between dehydrins and other proteins demonstrated the diversity of their physiological functions [9-11].

There are many excellent summaries on the roles of dehydrins. Yang et al. have summarized the different molecular mechanisms of dehydrins response to environmental stress in plants [12]. Poonam et al. provided a linked and comprehensive introduction of dehydrins gene family. Over the past 30 years, dehydrins have been known as chaperones which could protect plant from cold and free radical. Recent years we known dehydrins participate in regulation of genes that response to abiotic stress. Interestingly, dehydrins can also participate in histone modification [13]. However, as we know, few reviews have elaborated on dehydrin gene regulation at upstream signaling pathway. Dehydrin gene expression has been traditionally categorized as ABA-dependent and ABA-independent. Nevertheless, the existence of a crossing point between two pathways, some subsequent studies found. Therefore, dehydrin expression may, in fact, be regulated by multiple signal transduction pathways. The present review focuses on the complex dehydrins gene expression regulatory network and aims to elucidate the self-protection mechanism that dehydrins activate in plants challenged by abiotic stress.

\section{Dehydrin Structure, Classification, and Localization}

Dehydrins (DHNs) are thermostable, highly hydrophilic proteins with molecular weights in the range of 9-2000 kDa. They contain a characteristic lysine-rich K-segment near the $C$-terminus that can form an amphiphilic $\alpha$-helix conferring them with high hydrophilicity. A previous study showed that the K-segment binds the dehydrins to cell membranes [14] and protects LDH and antioxidont enzymes [15,16]. There are also other conserved motifs in the DHNs, containing the Y-segment and S-segment. Based on the presence of the K-, S-, and Y-segments, DHNs are classified into the Kn, SKn, KnS, YnKn, and YnSKn structural subgroups. Dehydrins have been detected in various plants. $\mathrm{YSK}_{2}-$ type RAB17 was found in maize, $\mathrm{SK}_{3}$-type COR410 and $\mathrm{YSK}_{2}$-type DHN5 occurred in wheat, $\mathrm{YSK}_{2}$ type ECP40 was identified in carrot, and $\mathrm{Y}_{2} \mathrm{~K}_{4}$-type CAS31 was observed in Medicago truncatula. Researchers have identified four dehydrin family genes from cucumbers, namely YnKn-type CsDHN1, YnSKn-type CsDHN2 and CsDHN4, and other SKn-type CsDHN3, all of which exhibit high proportion of alpha helix and random coils, similar to other plant dehydrins, and the other three dehydrins are all induced by drought, salt and ABA [17]. There are numerous dehydrins in the common model dicotyledon Arabidopsis and they are widely applied in stress biology. They include RAB18 $\left(\mathrm{Y}_{2} \mathrm{SK}_{2}-\right.$

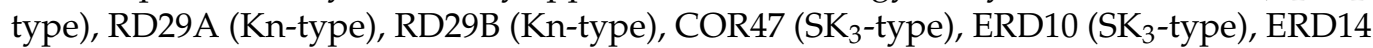
(SK 2 -type), and Lit30 (K $\mathrm{K}_{6}$-type). RD29A, RD29B, RAB18, COR47, and others are both dehydrin and abiotic stress marker genes.

Dehydrins abound in mature seeds and enable them to tolerate drought. In situ hybridization (ISH) revealed that MdoDHN11 was expressed in the central nucellus parenchyma layer between the endosperm and the testa in apple seeds [18]. Dehydrin localization changes with embryonic maturation. Maize RAB17 mRNA initially appeared in the embryo axis, was subsequently detected in the scutellum, and finally accumulated in the axis cells and provascular tissues [19]. Dehydrins may be found in many subcellular locations including the nucleus and the cytoplasm. Confocal microscopy disclosed that AtCOR47 and AtERD10 were localized to the cytoplasm whereas AtRAB18 was distributed in both the nucleus and the cytosol [10]. Maize RAB17 protein is distributed in the cytoplasm and nucleus, meanwhile its nuclear localization depends on nuclear localization signal (NLS) peptide binding via autophosphorylation [19]. Nuclear dehydrin localization was also reported for the embryonic axes of developing beech seeds [20]. Nuclear dehydrins are also regarded as protective substances in scattered chromatin [20]. Dehydrins may also occur in the plasma membrane and certain organelles such as the mitochondria and chloroplasts. AmDHN132 and AmDHN200 proteins were detected in the plasma membrane of transgenic Arabidopsis. Hence, they play roles in membrane protection [21]. 


\section{Dehydrins Participate in Plant Response to Abiotic Stress}

Dehydrins are Group II LEA proteins and play crucial roles in plant adaptation to abiotic stressors such as drought, cold, and salinity. There is substantial evidence that abiotic stress induces dehydrin expression.

\subsection{Dehydrin Expression under Drought Condition}

In many regions, plants are prone to drought during the summer season. Drought causes dehydration and cell damage and dehydrin genes are induced by dehydration stress. In white spruce, eight dehydrins responded to drought stress. The transcription levels of $P g D H N 10, P g D H N 16, P g D H N 33$, and $P g D H N 35$ increased several fold after a few days of water shortage [22]. Lv identified the novel YSK2-type dehydrin CdDHN4 in the Tifway and C299 bermudagrass varieties. CdDHN4 in the root and shoot was strongly upregulated by drought [23]. The dehydrin accumulation patterns varied with plant developmental stage during drought stress. The dehydrin profiles of winter wheat at the seedling, tillering, jointing, and anthesis stages differed from each other [24].

\subsection{Dehydrin Accumulation during Cold Stress}

Low temperatures may cause chilling or freezing injury in plants. Low temperature upsets the balance between root water absorption and leaf water transpiration, thereby causing dehydration. At subzero temperatures, extracellular ice crystals cause cellular dehydration and ultimate freezing injury. Plants challenged by water deficits and cold stress express cytoplasmic dehydrins in various tissues. Vítámvás et al. studied dehydrin accumulation in wheat and barley fields during wintertime. Relative dehydrin accumulation in winter wheat WCS120 and barley DHN5 was positively correlated with wintertime crop survival. Dehydrins and their transcripts might serve as cold tolerance markers [25]. In Arabidopsis thaliana, ERD10, ERD14, and Lti30 accumulate at low temperatures [26,27]. Research demonstrated that a combination of dehydrins and membranes improves plant cold tolerance. The K-segment of Lti30 combined with lipid head groups [14] via electrostatic interactions. In this manner, lipid and bound protein molecule mobility was limited and aggregates formed to protect the cell membrane [28].

\subsection{Dehydrin Expression Is Induced by Salt Stress}

High salt concentrations cause osmotic change, inhibit root water absorption, and eventually damage plant cells. Plants protect their cells from excessive water loss by accumulating dehydrins. As these proteins are highly hydrophilic, they bind large amounts of water and reduce water loss. High salinity induces dehydrin accumulation in the roots, stems, leaves, and seeds. Hernán et al. detected at least four dehydrins $(30 \mathrm{kDa}, 34 \mathrm{kDa}, 50 \mathrm{kDa}$, and $55 \mathrm{kDa}$ ) in Chenopodium quinoa embryos subjected to salt stress [29]. Salt treatment altered $\mathrm{CaDHN}$ expression. Relative to the untreated control, the salt-stressed plants presented with 134-fold and 420-fold increases in CaDHN5 and CaDHN7 expression and >20-fold increases in $C a D H N 1, C a D H N 2$, and $C a D H N 3$ expression [30]. A reversed genetics approach was used to explore the impact of dehydrin genes on plant salt tolerance enhancement. Under high $\mathrm{NaCl}$ concentrations, transgenic Arabidopsis thaliana overexpressing pepper CaDHN4 and CaDHN5 exhibited higher seed germination rates than WT plants [31,32]. GhDHN_03 and GhDHN_04 knockdown demonstrated the putative roles of dehydrins in augmenting osmotolerance and salt tolerance in cotton [33].

\section{Dehydrin Gene Expression Regulatory Networks}

Dehydrin expression is affected by various environmental factors. Drought, low temperature, and salinity rapidly induce dehydrin accumulation. Under abiotic stress, the regulation of dehydrin gene expression involves several classic signal transduction pathways, including ABA, MAPK, and $\mathrm{Ca}^{2+}$ (Figure 1), all of which activate transcription factor (TF) binding to the cis-acting elements in dehydrin promoter [34], thereby exerting various regulatory functions. 


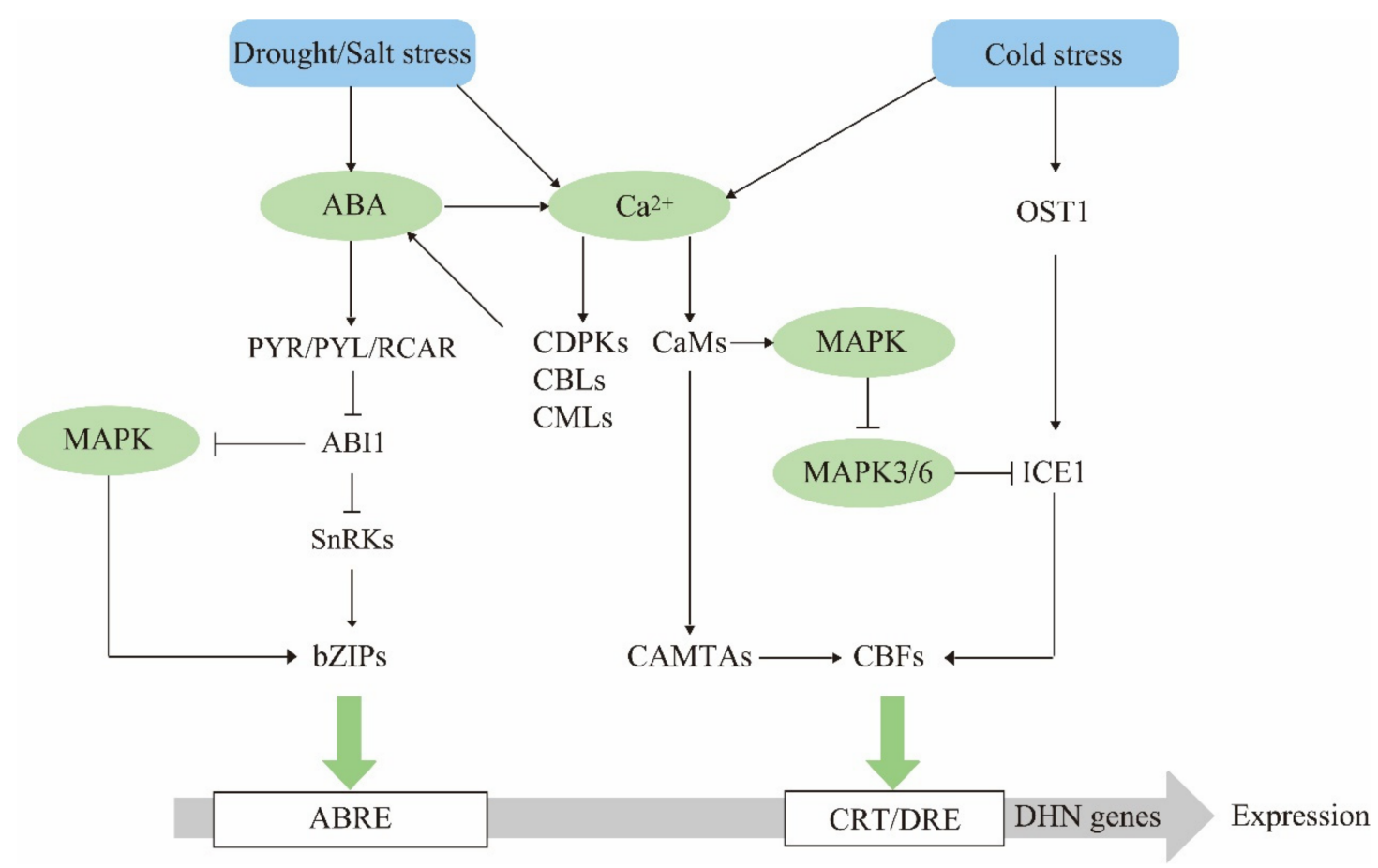

Figure 1. Dehydrin gene expression regulatory network model. Abiotic stressors such as drought, high salinity, and cold trigger dehydrin expression in plants depending on various signaling pathways. Drought and high salinity activate the ABA and calcium signaling pathways. After ABA binds its corresponding receptor, it acts on bZIP TFs and mediates dehydrin expression. Calcium ions are decoded by proteins such as CaMs, CDPKs, CBLs, and CMLs and regulate dehydrin expression via CBF TFs. They also act as bridges connecting drought/salinity and cold stress responses. ICE1 protein occurs in the early cold stress pathway. The CBFs in this pathway regulate the expression of multiple downstream CORs. The MAPK cascade also occurs throughout the entire regulatory network and regulates dehydrin expression upstream. Arrows and bars indicate positive and negative regulation, respectively.

\subsection{ABA Is a Dehydrin Mediator in Stress Response}

ABA is also called "anti-adversity hormone", and exogenous ABA treatment induces the expression of various dehydrins. Hence, the latter are considered responses to ABA proteins (RAB). Mundy and Chua identified the dehydrin gene RAB21 in rice roots, leaves, embryos, and cell suspensions treated with $\mathrm{ABA}(10 \mu \mathrm{M})$ or $\mathrm{NaCl}(200 \mathrm{mM})$ [35]. RAB18 mRNA accumulated in Arabidopsis thaliana exposed to exogenous ABA, cold, or water stress [36]. Subjecting wild type $A$. thaliana, an ABA-insensitive $A$. thaliana mutant (abi1), and an ABA-deficient $A$. thaliana mutant (aba-1) to low temperature demonstrated that the mutants were defective in the induction of RAB18. In the abi1 mutants, RAB18 expression was delayed. In the $a b a-1$ mutants, it was absent altogether [37]. Several cold stress-responsive dehydrin genes in A. thaliana such as Lti30 [38], COR39, and COR47 [39] may respond to exogenous ABA. Abscisic acid has various effects on the induction of different dehydrins. YnSKm-type DHN (YSK2-type TaDHN17) upregulation was detected in the leaves and roots of ABA-treated wheat seedlings whereas KS-type DHN (TaDHN1) expression was constant regardless of ABA treatment [40]. Therefore, dehydrin gene expression is regulated by both ABA-dependent and ABA-independent signaling pathways. Both types of pathways involve $\mathrm{Ca}^{2+}$ signaling which induces dehydrin gene expression under salinity, drought, and low temperature stress. Next, we will discuss the important roles of ABA core signal transduction pathways in dehydrin gene expression regulation.

The ABA signaling pathway is critical in plant drought and salt stress response. ABA receptors have been identified and core ABA signaling pathways have been elucidated [41] Various models have been proposed [41-43], including 'gate' and 'latch' model (Figure 2). These findings may facilitate the study of dehydrin gene expression regulation. PYLs (PYR/PYL/RCAR) and PP2Cs are ABA co-receptors [44]. ABA binds PYLs to form ABA- 
PYL complexes which, in turn, bind PP2Cs, inhibit their protein phosphatase activity, and release the SnRK2s that the PP2Cs had inhibited $[45,46]$. SnRK2s are activated by autophosphorylation. Thence, they phosphorylate numerous downstream ABA response effector proteins [47]. ABI5 (ABA-insensitive 5) and AREBs (ABA-responsive element binding proteins)/ABFs (ABA-responsive element-binding factors) in bZIP TFs are phosphorylated SnRK2 substrates [48,49]. A yeast two-hybrid $(\mathrm{Y} 2 \mathrm{H})$ system verified the interactions between FtbZIP83 and FtSnRK2.6/2.3 [50]. Bimolecular fluorescence complementary (BiFC) analysis showed that AREB1, AREB2, and ABF3 interact with SnRK2s [51]. ABA-responsive elements (ABREs) were detected in the dehydrin gene promoter regions of several different plant species. The OsDHNN-RAB16D promoter comprises eight ABA-responsive cis-acting elements [52]. WZY2 from wheat interacts with PP2C and its promoter contains several putative stress-related ABREs [53,54]. Thus, DHN expression may be regulated by ABA core pathways. CsSnRK2.5 overexpression conferred hypersensitivity to exogenous ABA. Transgenic Arabidopsis presented with elevated dehydrin levels compared to WT plants. Therefore, CsSnRK2.5 is a positive regulator of ABA-mediated dehydrin expression [55]. $V v A B F 2$ is a homolog of AREB/ABFs from Arabidopsis that was isolated from grapevine and constitutively expressed in Arabidopsis. This discovery confirmed the vital role of the AREB / ABF-SnRK2 pathway. Compared with WT Arabidopsis plants, VvABF2 transgenic plants were more sensitive to exogenous $\mathrm{ABA}$ and exhibited higher RAB18, LEA, and $R D 29 B$ expression levels and osmotolerance [56]. IbABF4 overexpression clearly improves expression level of $R D 29 A, R D 29 B, R A B 18$, and $R D 22$ [57]. However, the areb1-areb2-abf3 triple mutant was relatively more resistant to $\mathrm{ABA}$. Its stress-responsive genes $(R A B 18$ and $R D 29 B$ ) were downregulated and it displayed poor drought tolerance [51]. These findings suggested that the AREB/ABF-SnRK2 pathway plays a vital role in the dehydrin-regulated pathway under drought and salinity stress conditions. MYB TFs also regulate ABA on dehydrins. AtMYB44 interacts with the ABA receptor RCAR/PYL9, competes for the ABA receptor and $A B I 1$ binding sites, attenuates the inhibitory effect of ABI1, and downregulates $R A B 18$ [58]. Cotton $G h M Y B 73$ was rapidly induced by ABA and salinity and the transcription levels of $A t P Y L 8, A t A B F 3$, and $A t R D 29 B$ were significantly increased in its overexpressing lines. GhMYB73 interacted with AtPYL8 and its homolog GhPYL8. Hence, GhMYB73 may regulate ABA on dehydrins via PYL8 [59].

SnRK2s also regulate the expression of certain ABA-independent COR (cold-regulated) genes under cold stress [60]. OST1 (SnRK2.6) kinase is activated by low temperature stress and phosphorylates ICE1 which inhibits HOS1-mediated ICE1 ubiquitination and degradation. OST1 also competes with HOS1 for ICE1 binding and releases ICE1 from the HOS1-ICE1 complex. OST1 stabilizes ICE1 and the latter gradually accumulates and recognizes the C-repetitive binding factor $(\mathrm{CBF})$ promoters $[60,61]$. The latter are DNA regulatory elements in the $C O R$ promoter and contribute to plant cold adaptation [62]. CBF1, CBF2, and CBF3 are cold-induced CBF TFs in the Arabidopsis genome that bind CRT/DRE/LTRE [63]. Various dehydrins have been detected in cold-regulated proteins such as COR15a whose promoters contain CRT/DRE/LTRE elements [34]. Compared with the WT, CBF and downstream cold response genes such as AtRD29A, AtCOR15A, and AtCOR47 in the DIICE1- and SMICE1a overexpression lines were upregulated at low temperature and enhanced plant cold tolerance $[64,65]$. It was proposed that PaICE1 activates $P a C B F 1$ by binding MYC motifs in the PaCBF1 promoter, upregulating the downstream candidate gene $P a D H N 1$, and protecting plants from cold damage [66]. CBFs are regulated by ICE1 and are affected by phytochrome-interacting factor under cold stress. A recent model showed that $\mathrm{CBF}$ proteins accumulated under cold stress stabilized phytochrome $B$ by interacting with phytochrome-interacting factor3 (PIF3), and cold-stabilized phyB mediated PIF1, PIF4, and PIF5 degradation, thereby improving cold-regulated gene expression. Thus, COR expression may be coordinated by multiple TFs [67].

Regulation of gene expression by the DRE/CRT cis-element might be ABA-independent whereas gene expression regulated by the ABRE element may be ABA-dependent [68]. However, a recent study showed that there is cross-talk between these pathways in terms of 
gene expression regulation. The COR47 promoter contains two CRT/DRE/LTREs and one ABRE and its expression is induced by both cold and exogenous ABA [27]. ABA and LT synergistically upregulate the VvCBF2, VvCBF3, VvCBF4, and VvCBF6 TFs and promote antioxidant and dehydration gene expression and grape bud cold adaptation [69]. Certain DRE/CRT motifs also participate in the ABA-dependent pathway. In Arabidopsis, drought and ABA induce CBF4 expression. Constitutive CBF4 overexpression upregulates droughtand cold-related downstream genes containing DRE/CRT cis-elements such as COR47 and COR78/RD29A [70]. Under abiotic stress, OsDREB1F overexpression upregulated RD29A and COR15 $a$ with promoters bearing the DRE sequence and induced RD29B and RAB18 with promoters containing the ABRE (but not the DRE) element [71].

A

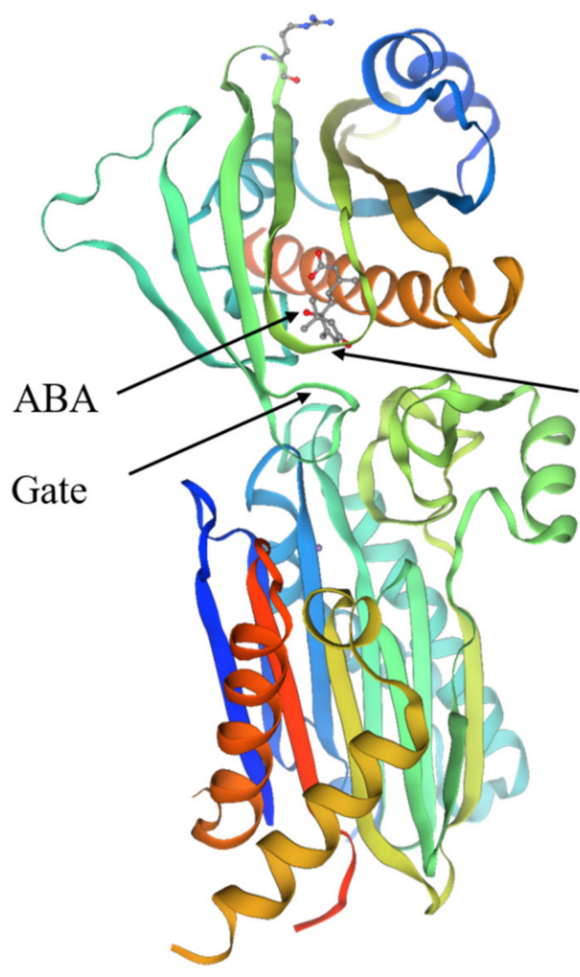

B

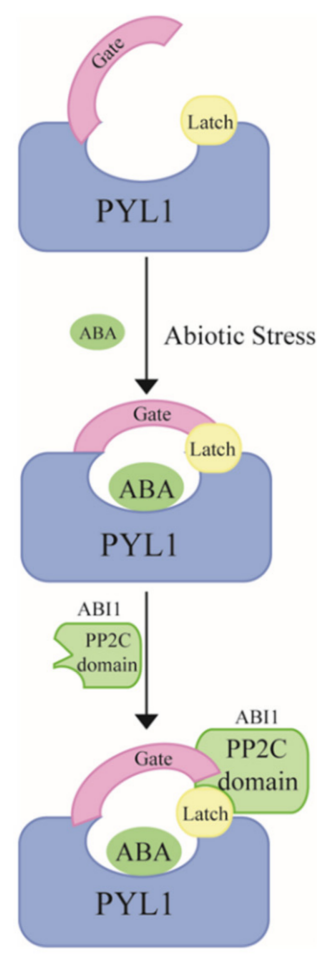

Figure 2. The interaction mechanism of ABA and ABA co-receptors. (A) The structure of the PYL1-ABA-ABI1 complex. The model and data come from the website (https: / / www.sib.swiss/, accessed on 17 November 2021). (B) The model of 'gate' and 'latch'. At first, the ABA receptor PYL1 in an open state. When the abiotic stress signal comes, ABA enters the receptor pocket and the gate loop is closed. Then interact with the PP2C domain of ABI1 to inhibit their protein phosphatase activity, causing activation of the SnRK2s-dependent phosphorylation pathways.

\subsection{The Calcium Signaling Pathway Has Multiple Regulatory Effects on Dehydrin Expression}

Abiotic stress conditions such as high salt, drought, and low temperature alter plant cell $\mathrm{Ca}^{2+}$ concentrations. $\mathrm{Ca}^{2+}$ is a second messenger that transmits external signals to plant cells and transduces the signals downstream to regulate various cellular processes such as gene expression via $\mathrm{Ca}^{2+}$ sensors. The latter consist mainly of CDPKs (calcium-dependent protein kinases), CBLs (calcineurin B-like proteins), CMLs (calmodulin-like proteins), and CaMs (calmodulins) which have complex EF hand domains that bind $\mathrm{Ca}^{2+}$. The calcium signal pathway has a wide range of regulatory effects on dehydrin expression (Figure 3).

CDPKs comprise serine/threonine protein kinase, autoinhibitory, and CaM-like domains [72,73]. Increases in $\mathrm{Ca}^{2+}$ concentration promote $\mathrm{Ca}^{2+}$ binding to the $\mathrm{N}$-terminus of the CML domain, change the conformation and shift of the autoinhibitory domain, and lead to intramolecular autophosphorylation and CDPK kinase activation [72]. Researchers identified 34, 26, and 27 members of the CDPK family in Arabidopsis, tea, and cassava [74-76], respectively. A previous review reported that CDPKs phosphorylate TFs 
in response to multiple abiotic stress-related pathways [77]. A current study disclosed that wheat TaCDPK9-1 (Triticum aestivum L.) activates TabZIP 8, TabZIP 9, and TabZIP 13 and regulates ABA synthesis and accumulation under salt stress. Thus, CDPKs might affect dehydrin gene expression downstream of ABA [78]. Arabidopsis CPK4, CPK11, and CPK32 kinases positively regulate $\mathrm{Ca}^{2+}$ implicated in ABA signaling by phosphorylating ABA-responsive bZIP TFs such as ABF1 and ABF4 [79,80]. These transcription factors bind the cis-acting regulatory elements of target genes and promote dehydrin response to abiotic stress. ABA strongly induced $A B F s$ and $R A B 18$ in transgenic $C P K 4$ and $C P K 11$ overexpression lines [80]. SnRKs also phosphorylate ABF TFs. Therefore, multiple kinases may regulate downstream target gene expression by acting on common substrates in the ABA signaling pathway. RT-PCR analysis revealed that AtCPK1 knockdown and overexpression inhibits and promotes RD29A and COR15A expression, respectively, under salinity and drought stress [81]. The foregoing results indicate that $C D P K$ family members positively regulate dehydrin expression and help plants contend with abiotic stress.

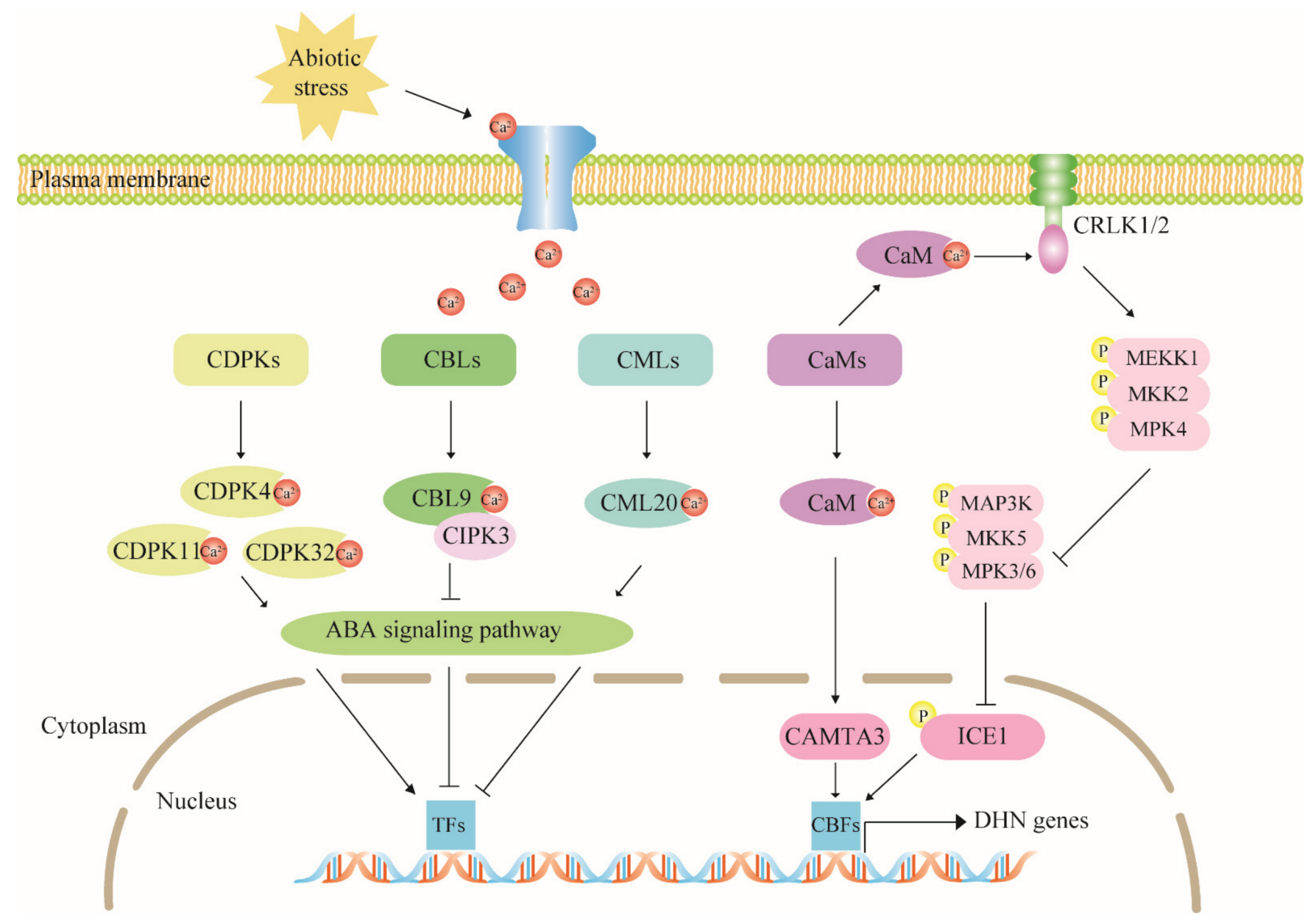

Figure 3. The calcium signal pathway has a wide range of regulatory effects on dehydrin expression. Sensors in the plasma

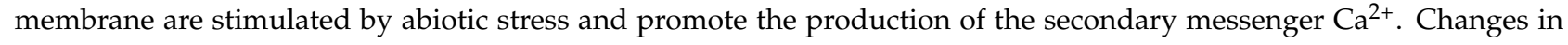
calcium concentration are perceived by the calcium sensor proteins CDPKs, CBLs, CMLs, and CaMs. The latter either participate in the ABA signaling pathway or initiate phosphorylation/dephosphorylation cascade reactions of TFs such as CAMTAs and CBFs that eventually participate in dehydrin gene activation. CRLK1/2 regulates COR in the upstream of the MEKK1-MKK2-MPK4 cascade pathway. We use arrows and bars showing positive and negative adjustment, respectively.

CBLs combine with their downstream gene family CIPKs to decode the calcium signal and initiate the stress response mechanism [82]. Seven and five CBLs and 20 and 15 CIPKs were identified in wheat and eggplant, respectively, and the interactions between these 
protein types were confirmed by $\mathrm{Y} 2 \mathrm{H}$ and BiFC assays $[83,84]$. Differential CBL expression under abiotic stress shows that this gene in implicated in the responses to various stressors such as drought, salinity, low temperature, and ABA. Recent research demonstrated that $C B L s$ were differentially expressed in transgenic rice seedlings subjected to drought and salt stress [85]. An overexpression analysis verified that OsCBL3 and OsCBL8 positively regulated salt tolerance while $O s C B L 5, O s C B L 6$, and OsCBL7 improved drought tolerance in rice. The Arabidopsis salt overly sensitive (SOS) pathway SOS3-SOS2 is a typical CBL-CIPK module also known as CBL4-CIPK24. It maintains intracellular $\mathrm{Na}^{2+}$ balance under high salt stress [86,87]. Numerous TFs regulating dehydrin gene expression have been identified as putative downstream signal components of the CBL-CIPK module. Under abiotic stress, $C B L$ and $C I P K$ overexpression and knockdown alter stress marker gene expression patterns. In Arabidopsis ectopically overexpressing TaCIPK27 and subjected to drought stress, $R D 29 B$ and $S n R K 2 S$ related to ABA signaling and DREB genes involved in drought stress response were significantly upregulated and improved drought tolerance [88]. The COR47 and KIN1 expression levels were markedly higher in TaCIPK23 overexpression lines than they were in the WT [89]. In CIPK3 T-DNA insertion mutants, cold-induced RD29A/COR78 expression was delayed and ABA-responsive $R D 22$ and $R D 29 B$ were downregulated [90]. The calcium-mediated CIPK3 pathway is a cross-node linking cold stress and the ABA signal transduction pathway. Li et al. discovered Arabidopsis Yin Yang 1(AtYYY1) which is a new negative regulator of $A B A$ response that is positively regulated by $A B A$ INSENSITIVE4 (ABI4). It binds the $A B A$ REPRESSOR1 (ABR1) promoter, upregulates $A B R 1$, and downregulates $R D 29 A, R D 29 B$, and COR15A [91]. Other researchers demonstrated that the CBL9-CIPK3 module acts upstream of ABR1 and may fine-tune ABA-responsive gene expression $[92,93]$.

CML proteins also have an EF hand structure which is a common calcium ion receptor in plants. Nevertheless, their biochemical characteristics are highly diverse among plant species [94]. Four CaMs and 36 CMLs were identified in a whole-genome analysis of woodland strawberry (Fragaria vesca). The simultaneous conservation and divergence of the FvCaM and FvCML gene structures resulted in functional similarities and differences [95]. Eighty-three CMLs were detected in the apple genome and were widely distributed in various tissues and organs. Most of them were induced by phytohormones and abiotic stress [96]. Of the 50 CMLs in Arabidopsis, CML20 negatively regulates dehydrin expression and ABA-induced stomatal movement. Drought and ABA upregulated stress response genes such as RAB18, ERD10, COR47, and RD29A in a cml20 mutant [97].

CaMs lack kinase activity. They must be combined with $\mathrm{Ca}^{2+}$ and form $\mathrm{Ca}^{2+}-\mathrm{CaM}$ complexes to alter molecular conformations and activate various downstream target proteins. The seven CaMs were found in the Arabidopsis genome [98], and four MdCaMs were recently identified in apple [99]. The calmodulin-binding transcriptional activator (CAMTA) family includes various TFs in the bZIP and MYB families. They contain DNA-binding domains and interact with $\mathrm{CaMs}$ to regulate the expression of downstream genes affected by stress signals and ABA [100,101]. However, CAMs may also regulate cold-induced gene expression. By contrast, CAMTA3 promotes cold-induced gene expression by upregulating CBF2 [102]. Neither CAMTA3 nor CAMTA5 is affected by gradual temperature decreases. However, precipitous declines in temperature cause them to promote CBF1 expression [103]. When Arabidopsis is subjected to cold, $\mathrm{Ca}^{2+} / \mathrm{CaM}$ interacts with AtCRLK1, activates the MAPK signal pathway, and upregulates COR [104,105]. Nevertheless, CaMs may also indirectly function as negative $C O R$ expression regulators. $C a M 3$ overexpression in Arabidopsis repressed both RD29A and COR6.6 [106].

\subsection{The MAPK Cascade Pathway Acts Upstream to Regulate Dehydrin Gene Expression}

Mitogen-activated protein kinase (MAPK) family members are involved in many biological processes and are crucial regulators of plant hormones and stress responses [107]. The MAPK cascade pathway includes the kinases MAP3K (MAPKKK or MEKK), MAP2K (MKK or MEK), and MAPK which are activated by sequential phosphorylation. Under 
cold stress, $\mathrm{Ca}^{2+}$ combines with CaM, activates the MAP cascade pathway, and upregulates cold-responsive genes $[104,105,108]$. In this process, MPK3 and MPK6 phosphorylate ICE1, thereby destabilizing it and decreasing its transcriptional activity [109]. ICE1 is subsequently ubiquitinated by E3 ligase and degraded in the proteasome. Thence, the CBF-controlled COR is downregulated [104]. In $m p k 3$ and $m p k 6$ single- and double mutants, $C B F s, C O R 15 A$, and RD29A trend higher levels, suggesting the positive effect of MAPK3/6 on dehydrin genes [108]. However, calcium/calmodulin-regulated receptor-like kinase 1 (CRLK1) is upregulated by calcium-calmodulin and activates the MEKK1-MKK2-MPK4 pathway [104,105]. MPK4 inhibits MPK3/6 activity [109]. Hence, the MEKK1-MKK2-MPK4 module plays an active upstream role in adjusting COR expression and cold tolerance (Figure 4).
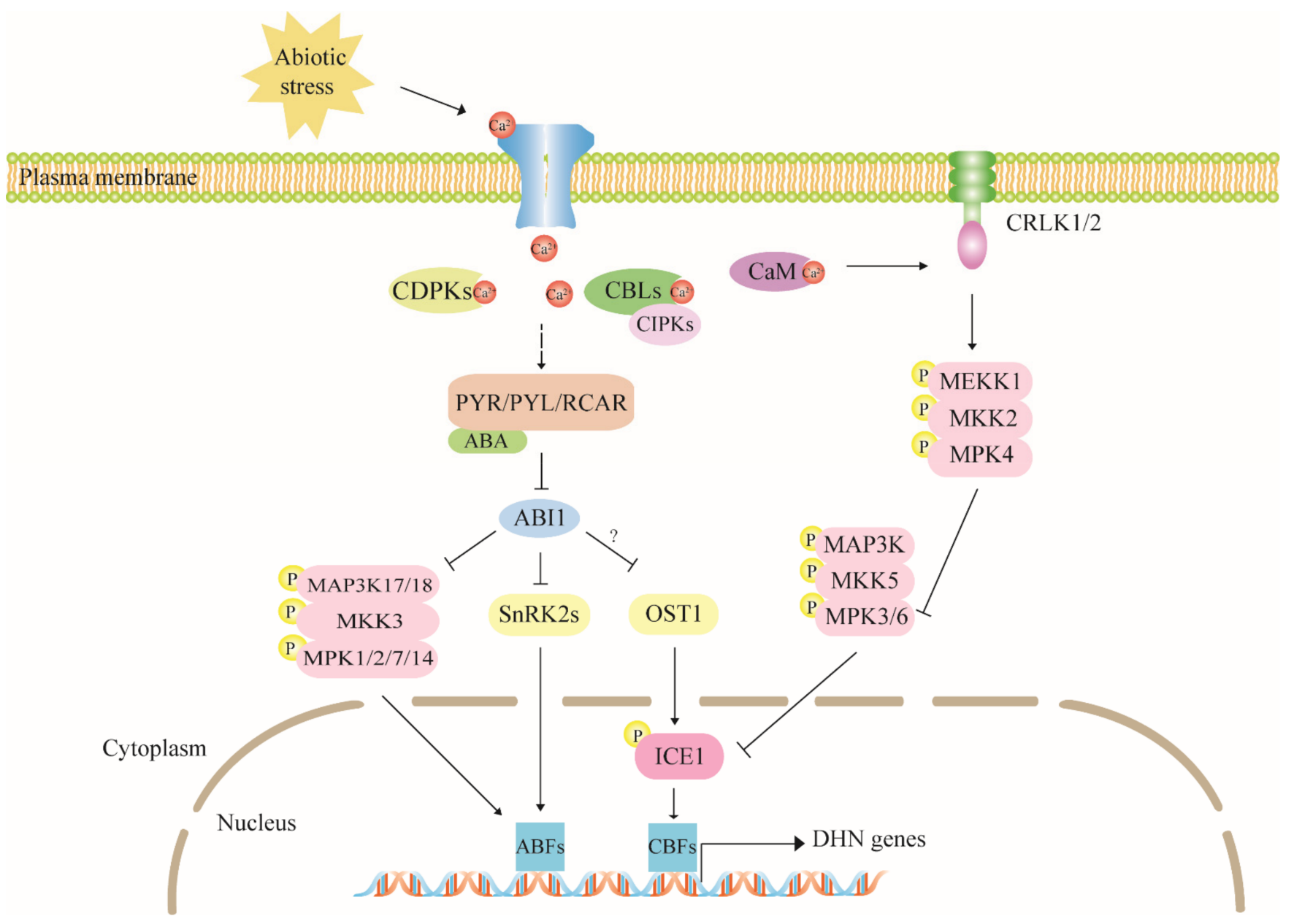

Figure 4. The MAPK cascade pathway is an upstream regulator of dehydrin gene expression. Under drought conditions, MAP3K-MKK3-MPK1/2/7/14 is activated by the core ABA component and regulates the expression of downstream dehydrins including RD29B and RAB18 by phosphorylating ABF TFs. In response to chilling, the MEKK1-MKK2-MPK4 cascade pathway is activated by Ca-CaM, counteracts the inhibitory effect of MAPK3/6 on ICE1, and upregulates downstream CORs. OST1 involved in the ABA signaling pathway can phosphorylate ICE1 to prevent its degradation and induce its accumulation. However, it is unclear whether ABA participates in this pathway. We use arrows and bars showing positive and negative adjustment, and solid and dashed lines indicate direct and indirect/unknown adjustment, respectively.

The ABA core pathway can activate MAPKs. PYR/PYL/RCAR-SnRK2-PP2C, known as the core ABA component, stimulates the MAP3K17/18-MKK3-MPK1/2/7/14 cascade pathway while the plant is subjected to drought and ABA stress [110]. MAP3K phosphorylates SnRK2.6/OST1 which are essential for ABA-triggered SnRK2 activation and promote TF phosphorylation and SLAC1 activation [111]. A transcriptome analysis revealed that 
MAP3K18 levels continued to rise throughout salt stress [112]. Mitula et al. demonstrated direct interactions among MAP3K18, PP2C phosphatase ABI1, and activation by ABA. This mechanism controls the expression of the ABA-regulated dehydrin genes $R D 29 B$ and RAB18 [113]. This discovery corroborates the hypothesis that the MAPK cascade acts upstream of dehydrin expression (Figure 4).

In the dehydrin expression regulatory mechanism challenged by abiotic stress, various signaling pathways decode the external stress signals, transmit them downstream, regulate the expression of stress response and dehydrin genes, and mediate plant stress adaptation. Each signaling pathway may act on different targets, crosstalk occurs among various signaling pathways, and both phenomena contribute to the formation of a complex and diverse regulatory network.

\section{Functional Diversity of Dehydrins}

\subsection{Dehydrins Protect Seeds from Dehydration during Maturation}

The plant water content often decreases during seed ripening. This mechanism is determined by plant genetics and is accompanied by LEA expression [114,115]. Dehydrins comprise a LEA subfamily and are usually synthesized and accumulated in the late stages of seed maturation. In this manner, they confer dehydration resistance to the seeds. The 26-kDa and 44-kDa dehydrins in Fagus sylvatica seeds determine the hypocotyl drying level during seed development [116]. In apple seed formation, DHN11 accumulates in the maternal nucleus and protects the embryo and endosperm against desiccation [18]. Dehydrins may stabilize cell membranes and proteins, thereby ensuring seed survival during maturation and drying.

\subsection{Dehydrins Stabilize Plasma Membranes}

Dehydrins are intrinsically disordered proteins that are induced by dehydration stress and low temperature. The structure and phase properties of the lipid bilayer of the plasma membrane are closely linked to temperature and water content. Extensive research has been conducted on the effects of dehydrins on the plasma membrane. The typical K-segments of dehydrins display high membrane affinity. During cold stress, the K-segment of Lti30 had a high membrane vesicle affinity. Binding was regulated by $\mathrm{pH}$-dependent His and phosphorylation, reduced the main lipid phase transition temperature, and stabilized the membrane [28,117]. An atomic-level analysis disclosed that the K-segments were partially folded into $\alpha$-helical segments on the membrane surface [14]. Dehydrins also interact with plasma membrane intrinsic proteins (PIPs) but do not bind membrane lipids. Plant PIPs are important members of the aquaporin (AQP) family. They are located on the membrane where they control abiotic stress-related water transport [118,119]. Hernandez-Sanchez et al. reported a homodimer interaction between AtCOR47 and AtERD10 [10]. AtCOR47, AtERD10, and AtRAB18 formed a heterotrimeric complex with OpsDHN1 from Opuntia streptacantha. Their mutual interactions protect proteins against abiotic stress damage [10]. BiFC technology revealed that AtPIP2Bs (Arabidopsis plasma membrane PIP family aquaporins) are common targets of OpsDHN1, AtCOR47, AtERD10, and AtRAB18 [11]. The interactions between dehydrins and AtPIP2B may prevent AQP denaturation and inactivation and stabilize the plasma membrane and its protein components under abiotic stress. Recently, it was demonstrated that under drought stress, the dehydrin MtCAS31 promotes autophagous degradation of MtPIP2;7 which is a negative regulator of the drought response. In this manner, it decreases root water loss and improves drought tolerance [120]. Hence, dehydrins have different effects on the plasma membrane components. Nevertheless, the mechanisms by which they exert their various protective effects remain to be elucidated.

\subsection{Dehydrins Protect Enzymatic Activity}

Abiotic stress induces ROS generation and accumulation in plant cells, thereby causing secondary oxidative stress and nucleic acid, protein, and lipid damage. Plants have evolved 
numerous defense mechanisms to maintain cellular redox homeostasis. For instance, plant antioxidant enzymes scavenge ROS. Dehydrins protect enzyme activity against oxidative stress. Under osmotic stress, ERD14 activated both glutathione transferase Phi9 and catalase [16,121]. The K-segments of DHNs protected lactate dehydrogenase (LDH) activity $[15,16]$. The AtHIRD11 His residue protected LDH against inactivation by heavy metals [122]. The hydrophobic residues of the F-segments in Arabidopsis COR47 (FSKntype dehydrin) protected LDH against inactivation by freezing [123]. Thus, dehydrins are multifunctional enzyme protectors and improve plant stress resistance [124]. Overexpression of dehydrin genes in many crops, such as wheat DHN5, rice DHN1, maize DHN11, and cucumber $L E A-S$, activates the plant antioxidant enzyme system, enhances the ability to remove active oxygen, and improves the stress tolerance ability $[16,125,126]$.

\subsection{Dehydrins Bind Metal Ions and DNA}

When plants suffer the effects of environmental stressors, metal ions in metalloproteins are released and promote ROS production. Several plant dehydrins combine with metal ions, reduce DNA and protein damage caused by ROS, and alleviate physiological disorders caused by heavy metals. Y2SK2 and YSK3 dehydrins from Agapanthus praecoxcan bound $\mathrm{Co}^{2+}, \mathrm{Ni}^{2+}, \mathrm{Cu}^{2+}$, and $\mathrm{Fe}^{3+}$ [124]. Vitis riparia DHN1 had strong binding affinity for $\mathrm{Zn}^{2+}$, $\mathrm{Ni}^{2+}, \mathrm{Cu}^{2+}$, and $\mathrm{Fe}^{2+}$ but not for $\mathrm{Mg}^{2+}$ or $\mathrm{Ca}^{2+}$ [127]. Arabidopsis KS-type dehydrins reversed the conformational changes in $\mathrm{LDH}$ caused by $\mathrm{Cu}^{2+}$ ions and restored enzyme activity more effectively than either bovine serum albumin (BSA) or lysozyme [122]. As dehydrins are also localized to the nucleus, they also protect nucleic acids. The S- and NLS-segments of ZmDHN13 localized it to the nucleus [16]. Nuclear VrDHN1 binds DNA. Its lysine-rich K-segment is positively charged and may bind the negatively charged phosphate backbone of DNA, thereby protecting it against ROS [127]. Table 1 is an overview of the functions of various plant dehydrins in abiotic stress response.

Table 1. Roles of dehydrins in abiotic stress tolerance in various plant species.

\begin{tabular}{|c|c|c|c|c|}
\hline Species & Dehydrin & Abiotic Stress Responses & Functions & References \\
\hline \multirow{5}{*}{ Arabidopsis thaliana } & RAB18 & Cold/drought/salinity & Freezing tolerance & [37] \\
\hline & COR47 & Cold & LDH cryoprotection & [123] \\
\hline & Lti30 & Cold & Membrane stabilization & {$[14,28,117]$} \\
\hline & ERD10 & Cold/drought/salinity & $\begin{array}{c}\text { Oxidoreductase protection, membrane stabilization, } \\
\text { chaperone activity }\end{array}$ & {$[121,128,129]$} \\
\hline & ERD14 & Cold/drought/salinity & Same as above & {$[121,128,129]$} \\
\hline \multirow[t]{2}{*}{ Agapanthus praecox } & $\begin{array}{c}\text { DHN } \\
(\mathrm{Y} 2 \mathrm{SK} 2)\end{array}$ & Cold/drought/salinity & $\begin{array}{l}\text { Metal ion binding, enzyme activity protection, } \\
\text { membrane cryoprotection }\end{array}$ & {$[124,130]$} \\
\hline & DHN (SK3) & Cold/drought/salinity & Same as above & {$[124,130]$} \\
\hline \multirow{4}{*}{$\begin{array}{l}\text { Ammopiptanthus } \\
\text { mongolicus }\end{array}$} & DHN132 & Cold/salinity & Membrane-protection & [21] \\
\hline & DHN154 & Cold/salinity & Same as above & [21] \\
\hline & DHN200 & Cold/salinity & Same as above & [21] \\
\hline & DHN3 & Drought/salinity & Upregulation of antioxidant enzyme system & [131] \\
\hline \multirow[t]{2}{*}{ Capsicum annuum } & DHN4 & Cold/salinity & $\begin{array}{l}\text { Cell membrane stabilization, prevention of lipid } \\
\text { peroxidation, inhibition of ROS accumulation }\end{array}$ & [32] \\
\hline & DHN5 & Salinity & Antioxidant capacity improvement & [31] \\
\hline Cerastium arcticum & DHN & Cold/drought/salinity & Oxidative stress tolerance & [132] \\
\hline Cucumis melo & $L E A-S$ & drought/salinity & APX and CAT activity enhancement & [133] \\
\hline Cucumis satious & DHN4 & Cold/ salinity / heat & LDH protection & {$[17,134]$} \\
\hline Ipomoea pescaprae & $\mathrm{DHN}$ & Cold/drought/salinity & Antioxidant enzyme system upregulation & [135] \\
\hline Maize & DHN11 & Cold/drought/salinity & antioxidant enzymes activity protection & [136] \\
\hline \multirow{3}{*}{ Medicago truncatula } & DHN13 & Cold & LDH protection & [16] \\
\hline & DHN1 & Cold/salinity & Membrane stabilization & [137] \\
\hline & CAS31 & Drought & Stomatal density and root water loss reduction & {$[120,138]$} \\
\hline Rice & DHN1 & drought/salinity & Enhancement of ROS scavenging capacity & [125] \\
\hline Saussurea involucrata & $\mathrm{DHN}$ & Cold/drought & $\begin{array}{l}\text { Inhibition of cell membrane damage, chloroplast } \\
\text { protection, enhancement of ROS scavenging capacity }\end{array}$ & {$[139]$} \\
\hline \multirow[t]{2}{*}{ Wheat } & COR410 & Cold/drought & $\begin{array}{c}\text { Plasma membrane protection against freezing and } \\
\text { dehydration stress }\end{array}$ & [140] \\
\hline & DHN5 & Cold/salinity & $\begin{array}{l}\text { LDH and bglG protection, and regulation of proline } \\
\text { metabolism and ROS scavenging system }\end{array}$ & {$[126,141]$} \\
\hline
\end{tabular}




\section{Conclusions and Perspectives}

The present review focused on the regulatory effects of ABA, MAPK, and second messenger calcium on dehydrin expression in plants under abiotic stress. This complex process involves diverse proteins and transcription factors. This review also addressed the physiological functions of dehydrins. However, several functional mechanisms of dehydrins remain to be elucidated. For example, hydrogen peroxide enters the plant cell via plasma membrane-intrinsic proteins (PIPs). It is unknown whether the interaction between dehydrins and PIPs affects $\mathrm{H}_{2} \mathrm{O}_{2}$ transport and participates in antioxidant protection.

Comprehensive analysis of the dehydrin gene expression regulatory network will increase our understanding of abiotic stress tolerance that developed during plant ecotype evolution. This finding will help clarify the plant self-protection mechanism and aid in the development and cultivation of high-yield crops that can tolerate adverse external environments.

Author Contributions: Wrote, reviewed, and edited the paper, Z.S.; revised the paper and gave positive suggestions on this article, S.L.; gave positive suggestions on this article, W.C., J.Z., L.Z.; revised the paper and gave positive suggestions, Z.W. and W.S. All authors have read and agreed to the published version of the manuscript.

Funding: This work was supported by the National Natural Science Foundation of China (No. 31970302), the Natural Science Foundation of Shandong Province, China (Grant No. ZR2017MC035), and the Science and Technology Development Planning of Shandong Province, China (Grant No. 2012GGB01136).

Institutional Review Board Statement: Not applicable.

Informed Consent Statement: Not applicable.

Conflicts of Interest: The authors declare no conflict of interest.

\section{References}

1. Zhang, H.; Zhu, J.; Gong, Z.; Zhu, J.-K. Abiotic stress responses in plants. Nat. Rev. Genet. 2021, 21, 413. [CrossRef] [PubMed]

2. Alam Syed, B.; Patel, M.; Patel, A.; Gami, B.; Patel, B. Regulation of antioxidant enzymes and osmo-protectant molecules by salt and drought responsive genes in Bambusa balcooa. J. Plant Res. 2021, 134, 165-175. [CrossRef]

3. Kaneko, K.; Lazarus, M.; Miyamoto, C.; Oishi, Y.; Nagata, N.; Yang, S.; Yoshikawa, M.; Aritake, K.; Furuyashiki, T.; Narumiya, S.; et al. Orally administered rubiscolin-6, a delta opioid peptide derived from Rubisco, stimulates food intake via leptomeningeal lipocallin-type prostaglandin D synthase in mice. Mol. Nutr. Food Res. 2012, 56, 1315-1323. [CrossRef]

4. Yoshikawa, M. Bioactive peptides derived from natural proteins with respect to diversity of their receptors and physiological effects. Peptides 2015, 72, 208-225. [CrossRef]

5. Stefanucci, A.; Dimmito, M.P.; Tenore, G.; Pieretti, S.; Minosi, P.; Zengin, G.; Sturaro, C.; Calò, G.; Novellino, E.; Cichelli, A.; et al. Plant-derived peptides rubiscolin-6, soymorphin-6 and their c-terminal amide derivatives: Pharmacokinetic properties and biological activity. J. Funct. Foods 2020, 73, 104154. [CrossRef]

6. Soba, D.; Müller, M.; Aranjuelo, I.; Munné-Bosch, S. Vitamin E in legume nodules: Occurrence and antioxidant function. Phytochemistry 2020, 172, 112261. [CrossRef]

7. Jin, X.; Cao, D.; Wang, Z.; Ma, L.; Tian, K.; Liu, Y.; Gong, Z.; Zhu, X.; Jiang, C.; Li, Y. Genome-wide identification and expression analyses of the LEA protein gene family in tea plant reveal their involvement in seed development and abiotic stress responses. Sci. Rep. 2019, 9, 14123. [CrossRef]

8. Shen, X.; Wang, Z.; Song, X.; Xu, J.; Jiang, C.; Zhao, Y.; Ma, C.; Zhang, H. Transcriptomic profiling revealed an important role of cell wall remodeling and ethylene signaling pathway during salt acclimation in Arabidopsis. Plant Mol. Biol. 2014, 86, 303-317. [CrossRef]

9. Maryan, K.E.; Lahiji, H.S.; Farrokhi, N.; Komeleh, H.H. Analysis of Brassica napus dehydrins and their Co-Expression regulatory networks in relation to cold stress. Gene Expr. Patterns 2019, 31, 7-17. [CrossRef]

10. Sánchez, I.E.H.; Maruri-López, I.; Graether, S.P.; Jiménez-Bremont, J.F. In vivo evidence for homo- and heterodimeric interactions of Arabidopsis thaliana dehydrins AtCOR47, AtERD10, and AtRAB18. Sci. Rep. 2017, 7, 17036. [CrossRef]

11. Hernández-Sánchez, I.E.; Maruri-López, I.; Molphe-Balch, E.P.; Becerra-Flora, A.; Jaimes-Miranda, F.; Jiménez-Bremont, J.F. Evidence for in vivo interactions between dehydrins and the aquaporin AtPIP2B. Biochem. Biophys. Res. Commun. 2019, 510, 545-550. [CrossRef]

12. Liu, Y.; Song, Q.; Li, D.; Yang, X.; Li, D. Multifunctional roles of plant dehydrins in response to environmental stresses. Front. Plant Sci. 2017, 8, 1018. [CrossRef] 
13. Tiwari, P.; Chakrabarty, D. Dehydrin in the past four decades: From chaperones to transcription co-regulators in regulating abiotic stress response. Curr. Res. Biotechnol. 2021, 3, 249-259. [CrossRef]

14. Eriksson, S.; Eremina, N.; Barth, A.; Danielsson, J.; Harryson, P. Membrane-Induced Folding of the Plant Stress Dehydrin Lti30. Plant Physiol. 2016, 171, 932-943.

15. Hara, M.; Endo, T.; Kamiya, K.; Kameyama, A. The role of hydrophobic amino acids of K-segments in the cryoprotection of lactate dehydrogenase by dehydrins. J. Plant Physiol. 2017, 210, 18-23. [CrossRef]

16. Liu, Y.; Wang, L.; Zhang, T.; Yang, X.; Li, D. Functional characterization of KS-type dehydrin ZmDHN13 and its related conserved domains under oxidative stress. Sci. Rep. 2017, 7, 7361. [CrossRef]

17. Zhou, Y.; Hu, L.; Xu, S.; Jiang, L.; Liu, S. Identification and transcriptional analysis of dehydrin gene family in cucumber (Cucumis sativus). Acta Physiol. Plant. 2018, 40,144. [CrossRef]

18. Da Falavigna, V.S.; Malabarba, J.; Silveira, C.P.; Buffon, V.; de Mariath, J.E.A.; Pasquali, G.; Margis-Pinheiro, M.; Revers, L.F. Characterization of the nucellus-specific dehydrin MdoDHN11 demonstrates its involvement in the tolerance to water deficit. Plant Cell Rep. 2019, 38, 1099-1107. [CrossRef]

19. Goday, A.; Jensen, A.B.; Culiáñez-Macià, F.A.; Mar Albà, M.; Figueras, M.; Serratosa, J.; Torrent, M.; Pagès, M. The maize abscisic acid-responsive protein Rab17 is located in the nucleus and interacts with nuclear localization signals. Plant Cell 1994, 6, 351-360.

20. Kalemba, E.M.; Bagniewska-Zadworna, A.; Ratajczak, E. Multiple subcellular localizations of dehydrin-like proteins in the embryonic axes of common beech (Fagus sylvatica L.) seeds during maturation and dry storage. J. Plant Growth Regul. 2015, 34, 137-149. [CrossRef]

21. Cui, H.; Wang, Y.; Yu, T.; Chen, S.; Chen, Y.; Lu, C. Heterologous expression of three ammopiptanthus mongolicus dehydrin genes confers abiotic stress tolerance in Arabidopsis thaliana. Plants 2020, 9, 193. [CrossRef]

22. Sena, J.S.; Giguère, I.; Rigault, P.; Bousquet, J.; Mackay, J. Expansion of the dehydrin gene family in the Pinaceae is associated with considerable structural diversity and drought-responsive expression. Tree Physiol. 2018, 38, 442-456. [CrossRef]

23. Lv, A.; Fan, N.; Xie, J.; Yuan, S.; An, Y.; Zhou, P. Expression of CdDHN4, a novel YSK2-type dehydrin gene from bermudagrass, responses to drought stress through the ABA-dependent signal pathway. Front. Plant Sci. 2017, 8, 748. [CrossRef]

24. Zhang, H.M.; Zhang, L.S.; Liu, L.; Zhu, W.N.; Yang, W.B. Changes of dehydrin profiles induced by drought in winter wheat at different developmental stages. Biol. Plant. 2013, 57, 797-800. [CrossRef]

25. Vítámvás, P.; Kosová, K.; Musilová, J.; Holková, L.; Mař́ik, P.; Smutná, P.; Klíma, M.; Prášil, I.T. Relationship between dehydrin accumulation and winter survival in winter wheat and barley grown in the field. Front. Plant Sci. 2019, 10, 7. [CrossRef]

26. Kiyosue, T.; Yamaguchi-Shinozaki, K.; Shinozaki, K. Characterization of two cDNAs (ERD10 and ERD14) corresponding to genes that respond rapidly to dehydration stress in Arabidopsis thaliana. Plant Cell Physiol. 1994, 35, 225-231. [CrossRef]

27. Welin, B.V.; Olson, A.; Palva, E.T. Structure and organization of two closely related low-temperature-induced dhn/lea/rab-like genes in Arabidopsis thaliana L. Heynh. Plant Mol. Biol. 1995, 29, 391-395. [CrossRef]

28. Gupta, A.; Marzinek, J.K.; Jefferies, D.; Bond, P.J.; Harryson, P.; Wohland, T. The disordered plant dehydrin Lti30 protects the membrane during water-related stress by cross-linking lipids. J. Biol. Chem. 2019, 294, 6468-6482. [CrossRef]

29. Burrieza, H.P.; Koyro, H.-W.; Tosar, L.M.; Kobayashi, K.; Maldonado, S. High salinity induces dehydrin accumulation in Chenopodium quinoa Willd. cv. Hualhuas embryos. Plant Soil 2011, 354, 69-79. [CrossRef]

30. Jing, H.; Li, C.; Ma, F.; Ma, J.-H.; Khan, A.; Wang, X.; Zhao, L.-Y.; Gong, Z.-H.; Chen, R.-G. Genome-wide identification, expression diversication of dehydrin gene family and characterization of CaDHN3 in pepper (Capsicum annuum L.). PLoS ONE 2016, 11, e0161073. [CrossRef]

31. Luo, D.; Hou, X.; Zhang, Y.; Meng, Y.; Zhang, H.; Liu, S.; Wang, X.; Chen, R. CaDHN5, a dehydrin gene from pepper, plays an important role in salt and osmotic stress responses. Int. J. Mol. Sci. 2019, 20, 1989. [CrossRef] [PubMed]

32. Zhang, H.-F.; Liu, S.-Y.; Ma, J.-H.; Wang, X.-K.; Haq, S.U.; Meng, Y.-C.; Zhang, Y.-M.; Chen, R.-G. CaDHN4, a salt and cold stress-responsive dehydrin gene from pepper decreases abscisic acid sensitivity in Arabidopsis. Int. J. Mol. Sci. 2019, 21, 26. [CrossRef]

33. Kirungu, J.N.; Magwanga, R.O.; Pu, L.; Cai, X.; Xu, Y.; Hou, Y.; Zhou, Y.; Cai, Y.; Hao, F.; Zhou, Z.; et al. Knockdown of Gh_A05G1554 (GhDHN_03) and Gh_D05G1729 (GhDHN_04) dehydrin genes, reveals their potential role in enhancing osmotic and salt tolerance in cotton. Genomics 2020, 112, 1902-1915. [CrossRef]

34. Zolotarov, Y.; Strömvik, M. De novo regulatory motif discovery identifies significant motifs in promoters of five classes of plant dehydrin genes. PLoS ONE 2015, 10, e0129016. [CrossRef]

35. Mundy, J.; Chua, N.H. Abscisic acid and water-stress induce the expression of a novel rice gene. EMBO J. 1988, 7, 2279-2286. [CrossRef]

36. Lång, V.; Palva, E.T. The expression of a rab-related gene, rab18, is induced by abscisic acid during the cold acclimation process of Arabidopsis thaliana (L.) Heynh. Plant Mol. Biol. 1992, 20, 951-962. [CrossRef]

37. Mantyla, E.; Lang, V.; Palva, E.T. Role of abscisic acid in drought-induced freezing tolerance, cold acclimation, and accumulation of LT178 and RAB18 proteins in Arabidopsis thaliana. Plant Physiol. 1995, 107, 141-148. [CrossRef]

38. Rouse, D.T.; Marotta, R.; Parish, R.W. Promoter and expression studies on an Arabidopsis thaliana dehydrin gene. FEBS Lett. 1996, 381, 252-256. [CrossRef]

39. Guo, W.; Ward, R.W.; Thomashow, M.F. Characterization of a cold-regulated wheat gene related to Arabidopsis cor47. Plant Physiol. 1992, 100, 915-922. [CrossRef] [PubMed] 
40. Wang, Y.; Xu, H.; Zhu, H.; Tao, Y.; Zhang, G.; Zhang, L.; Zhang, C.; Zhang, Z.; Ma, Z. Classification and expression diversification of wheat dehydrin genes. Plant Sci. 2014, 214, 113-120. [CrossRef]

41. Miyazono, K.-I.; Miyakawa, T.; Sawano, Y.; Kubota, K.; Kang, H.-J.; Asano, A.; Miyauchi, Y.; Takahashi, M.; Zhi, Y.; Fujita, Y.; et al. Structural basis of abscisic acid signalling. Nature 2009, 462, 609-614. [CrossRef]

42. Ng, L.M.; Melcher, K.; Teh, B.T.; Xu, H.E. Abscisic acid perception and signaling: Structural mechanisms and applications. Acta Pharmacol. Sin. 2014, 35, 567-584. [CrossRef] [PubMed]

43. Raghavendra, A.S.; Gonugunta, V.K.; Christmann, A.; Grill, E. ABA perception and signalling. Trends Plant Sci. 2010, 15, 395-401. [CrossRef]

44. Park, S.-Y.; Fung, P.; Nishimura, N.; Jensen, D.R.; Fujii, H.; Zhao, Y.; Lumba, S.; Santiago, J.; Rodrigues, A.; Chow, T.-F.F.; et al. Abscisic acid inhibits type 2C protein phosphatases via the PYR/PYL family of START proteins. Science 2009, 324, $1068-1071$. [CrossRef]

45. Ma, Y.; Szostkiewicz, I.; Korte, A.; Moes, D.; Yang, Y.; Christmann, A.; Grill, E. Regulators of PP2C phosphatase activity function as abscisic acid sensors. Science 2009, 324, 1064-1068. [CrossRef]

46. Soon, F.-F.; Ng, L.-M.; Zhou, X.E.; West, G.M.; Kovach, A.; Tan, M.H.E.; Suino-Powell, K.M.; He, Y.; Xu, Y.; Chalmers, M.J.; et al. Molecular mimicry regulates ABA signaling by SnRK2 kinases and PP2C phosphatases. Science 2012, 335, 85-88. [CrossRef]

47. Zhu, J.-K. Abiotic stress signaling and responses in plants. Cell 2016, 167, 313-324. [CrossRef]

48. Skubacz, A.; Daszkowska-Golec, A.; Szarejko, I. The role and regulation of ABI5 (ABA-Insensitive 5) in plant development, abiotic stress responses and phytohormone crosstalk. Front. Plant Sci. 2016, 7, 1884. [CrossRef] [PubMed]

49. Umezawa, T.; Sugiyama, N.; Takahashi, F.; Anderson, J.C.; Ishihama, Y.; Peck, S.C.; Shinozaki, K. Genetics and phosphoproteomics reveal a protein phosphorylation network in the abscisic acid signaling pathway in Arabidopsis thaliana. Sci. Signal. 2013, 6, rs8. [CrossRef]

50. Li, Q.; Wu, Q.; Wang, A.; Lv, B.; Dong, Q.; Yao, Y.; Wu, Q.; Zhao, H.; Li, C.; Chen, H.; et al. Tartary buckwheat transcription factor FtbZIP83 improves the drought/salt tolerance of Arabidopsis via an ABA-mediated pathway. Plant Physiol. Biochem. 2019, 144, 312-323. [CrossRef] [PubMed]

51. Yoshida, T.; Fujita, Y.; Sayama, H.; Kidokoro, S.; Maruyama, K.; Mizoi, J.; Shinozaki, K.; Yamaguchi-Shinozaki, K. AREB1, AREB2, and ABF3 are master transcription factors that cooperatively regulate ABRE-dependent ABA signaling involved in drought stress tolerance and require ABA for full activation. Plant J. 2010, 61, 672-685. [CrossRef] [PubMed]

52. Tiwari, P.; Indoliya, Y.; Singh, P.K.; Singh, P.C.; Chauhan, P.S.; Pande, V.; Chakrabarty, D. Role of dehydrin-FK506-binding protein complex in enhancing drought tolerance through the ABA-mediated signaling pathway. Environ. Exp. Bot. 2019, 158, 136-149. [CrossRef]

53. Liu, H.; Yang, Y.; Zhang, L. Identification of upstream transcription factors and an interacting PP2C protein of dehydrin WZY2 gene in wheat. Plant Signal. Behav. 2019, 14, 1678370. [CrossRef] [PubMed]

54. Zhu, W.; Zhang, L.; Lv, H.; Zhang, H.; Zhang, D.; Wang, X.; Chen, J. The dehydrin wzy2 promoter from wheat defines its contribution to stress tolerance. Funct. Integr. Genom. 2014, 14, 111-125. [CrossRef] [PubMed]

55. Zhang, Y.; Wan, S.; Liu, X.; He, J.; Cheng, L.; Duan, M.; Liu, H.; Wang, W.; Yu, Y. Overexpression of CsSnRK2.5 increases tolerance to drought stress in transgenic Arabidopsis. Plant Physiol. Biochem. 2020, 150, 162-170. [CrossRef] [PubMed]

56. Liu, J.; Chu, J.; Ma, C.; Jiang, Y.; Ma, Y.; Xiong, J.; Cheng, Z.-M. Overexpression of an ABA-dependent grapevine bZIP transcription factor, VvABF2, enhances osmotic stress in Arabidopsis. Plant Cell Rep. 2019, 38, 587-596. [CrossRef]

57. Wang, W.; Qiu, X.; Yang, Y.; Kim, H.S.; Jia, X.; Yu, H.; Kwak, S.-S. Sweetpotato bZIP transcription factor IbABF4 confers tolerance to multiple abiotic stresses. Front. Plant Sci. 2019, 10, 630. [CrossRef]

58. Li, D.; Li, Y.; Zhang, L.; Wang, X.; Zhao, Z.; Tao, Z.; Wang, J.; Wang, J.; Lin, M.; Li, X.; et al. Arabidopsis ABA receptor RCAR1/PYL9 interacts with an R2R3-type MYB transcription factor, AtMYB44. Int. J. Mol. Sci. 2014, 15, 8473-8490. [CrossRef]

59. Zhao, Y.; Yang, Z.; Ding, Y.; Liu, L.; Han, X.; Zhan, J.; Wei, X.; Diao, Y.; Qin, W.; Wang, P.; et al. Over-expression of an R2R3 MYB gene, GhMYB73, increases tolerance to salt stress in transgenic Arabidopsis. Plant Sci. 2019, 286, 28-36. [CrossRef]

60. Ding, Y.; Li, H.; Zhang, X.; Xie, Q.; Gong, Z.; Yang, S. OST1 kinase modulates freezing tolerance by enhancing ICE1 stability in Arabidopsis. Dev. Cell 2015, 32, 278-289. [CrossRef]

61. Tang, K.; Zhao, L.; Ren, Y.; Yang, S.; Zhu, J.-K.; Zhao, C. The transcription factor ICE1 functions in cold stress response by binding to the promoters of CBF and COR genes. J. Integr. Plant Biol. 2020, 62, 258-263. [CrossRef]

62. Park, S.; Lee, C.-M.; Doherty, C.J.; Gilmour, S.J.; Kim, Y.; Thomashow, M.F. Regulation of the Arabidopsis CBF regulon by a complex low-temperature regulatory network. Plant J. 2015, 82, 193-207. [CrossRef]

63. Gilmour, S.J.; Fowler, S.G.; Thomashow, M.F. Arabidopsis transcriptional activators CBF1, CBF2, and CBF3 have matching functional activities. Plant Mol. Biol. 2004, 54, 767-781. [CrossRef]

64. Yang, X.; Wang, R.; Hu, Q.; Li, S.; Mao, X.; Jing, H.; Zhao, J.; Hu, G.; Fu, J.; Liu, C. DlICE1, a stress-responsive gene from Dimocarpus longan, enhances cold tolerance in transgenic Arabidopsis. Plant Physiol. Biochem. 2019, 142, 490-499. [CrossRef]

65. Zhou, L.; He, Y.J.; Li, J.; Li, L.; Liu, Y.; Chen, H.Y. An eggplant SmICE1a gene encoding MYC-type ICE1-like transcription factor enhances freezing tolerance in transgenic Arabidopsis thaliana. Plant Biol. 2020, 22, 450-458. [CrossRef] [PubMed]

66. Peng, P.-H.; Lin, C.-H.; Tsai, H.-W.; Lin, T.-Y. Cold response in Phalaenopsis aphrodite and characterization of PaCBF1 and PaICE1. Plant Cell Physiol. 2014, 55, 1623-1635. [CrossRef] [PubMed] 
67. Jiang, B.; Shi, Y.; Peng, Y.; Jia, Y.; Yan, Y.; Dong, X.; Li, H.; Dong, J.; Li, J.; Gong, Z.; et al. Cold-induced CBF-PIF3 interaction enhances freezing tolerance by stabilizing the phyB thermosensor in Arabidopsis. Mol. Plant 2020, 13, 894-906. [CrossRef]

68. Chinnusamy, V.; Zhu, J.; Zhu, J.-K. Salt stress signaling and mechanisms of plant salt tolerance. Genet. Eng. 2006, 27, 141-177.

69. Rubio, S.; Noriega, X.; Pérez, F.J. Abscisic acid (ABA) and low temperatures synergistically increase the expression of CBF/DREB1 transcription factors and cold-hardiness in grapevine dormant buds. Ann. Bot. 2019, 123, 681-689. [CrossRef]

70. Li, J.; Wang, N.; Xin, H.; Li, S. Overexpression of VaCBF4, a transcription factor from Vitis amurensis, improves cold tolerance accompanying increased resistance to drought and salinity in Arabidopsis. Plant Mol. Biol. Rep. 2013, 31, 1518-1528. [CrossRef]

71. Wang, Q.; Guan, Y.; Wu, Y.; Chen, H.; Chen, F.; Chu, C. Overexpression of a rice OsDREB1F gene increases salt, drought, and low temperature tolerance in both Arabidopsis and rice. Plant Mol. Biol. 2008, 67, 589-602. [CrossRef] [PubMed]

72. Liese, A.; Romeis, T. Biochemical regulation of in vivo function of plant calcium-dependent protein kinases (CDPK). Biochim. Biophys. Acta 2013, 1833, 1582-1589. [CrossRef] [PubMed]

73. Ormancey, M.; Thuleau, P.; Mazars, C.; Cotelle, V. CDPKs and 14-3-3 proteins: Emerging duo in signaling. Trends Plant Sci. 2017, 22, 263-272. [CrossRef]

74. Cheng, S.-H.; Willmann, M.R.; Chen, H.-C.; Sheen, J. Calcium signaling through protein kinases. The arabidopsis calciumdependent protein kinase gene family. Plant Physiol. 2002, 129, 469-485. [CrossRef]

75. Ding, C.; Lei, L.; Yao, L.; Wang, L.; Hao, X.; Li, N.; Wang, Y.; Yin, P.; Guo, G.; Yang, Y.; et al. The involvements of calcium-dependent protein kinases and catechins in tea plant [Camellia sinensis (L.) O. Kuntze] cold responses. Plant Physiol. Biochem. 2019, 143, 190-202. [CrossRef] [PubMed]

76. Hu, W.; Hou, X.; Xia, Z.; Yan, Y.; Wei, Y.; Wang, L.; Zou, M.; Lu, C.; Wang, W.; Peng, M. Genome-wide survey and expression analysis of the calcium-dependent protein kinase gene family in cassava. Mol. Genet. Genom. 2016, 291, 241-253. [CrossRef]

77. Atif, R.M.; Shahid, L.; Waqas, M.; Ali, B.; Rashid, M.A.R.; Azeem, F.; Nawaz, M.A.; Wani, S.H.; Chung, G. Insights on calciumdependent protein kinases (CPKs) signaling for abiotic stress tolerance in plants. Int. J. Mol. Sci. 2019, 20, 5298. [CrossRef]

78. Zhang, L.; Xie, J.; Wang, L.; Si, L.; Zheng, S.; Yang, Y.; Yang, H.; Tian, S. Wheat TabZIP8, 9, 13 participate in ABA biosynthesis in $\mathrm{NaCl}$-stressed roots regulated by TaCDPK9-1. Plant Physiol. Biochem. 2020, 151, 650-658. [CrossRef]

79. Choi, H.-I.; Park, H.-J.; Park, J.H.; Kim, S.; Im, M.-Y.; Seo, H.-H.; Kim, Y.-W.; Hwang, I.; Kim, S.Y. Arabidopsis calcium-dependent protein kinase AtCPK32 interacts with ABF4, a transcriptional regulator of abscisic acid-responsive gene expression, and modulates its activity. Plant Physiol. 2005, 139, 1750-1761. [CrossRef]

80. Zhu, S.-Y.; Yu, X.-C.; Wang, X.-J.; Zhao, R.; Li, Y.; Fan, R.-C.; Shang, Y.; Du, S.-Y.; Wang, X.-F.; Wu, F.-Q.; et al. Two calciumdependent protein kinases, CPK4 and CPK11, regulate abscisic acid signal transduction in Arabidopsis. Plant Cell 2007, 19, 3019-3036. [CrossRef]

81. Huang, K.; Peng, L.; Liu, Y.; Yao, R.; Liu, Z.; Li, X.; Yang, Y.; Wang, J. Arabidopsis calcium-dependent protein kinase AtCPK1 plays a positive role in salt/drought-stress response. Biochem. Biophys. Res. Commun. 2018, 498, 92-98. [CrossRef]

82. Tang, R.-J.; Wang, C.; Li, K.; Luan, S. The CBL-CIPK calcium signaling network: Unified paradigm from 20 years of discoveries. Trends Plant Sci. 2020, 25, 604-617. [CrossRef] [PubMed]

83. Li, J.; Jiang, M.-M.; Ren, L.; Liu, Y.; Chen, H.-Y. Identification and characterization of CBL and CIPK gene families in eggplant (Solanum melongena L.). Mol. Genet. Genom. 2016, 291, 1769-1781. [CrossRef]

84. Sun, T.; Wang, Y.; Wang, M.; Li, T.; Zhou, Y.; Wang, X.; Wei, S.; He, G.; Yang, G. Identification and comprehensive analyses of the CBL and CIPK gene families in wheat (Triticum aestivum L.). BMC Plant Biol. 2015, 15, 269. [CrossRef] [PubMed]

85. Jiang, M.; Zhao, C.; Zhao, M.; Li, Y.; Wen, G. Phylogeny and evolution of Calcineurin B-Like (CBL) gene family in grass and functional analyses of rice CBLs. J. Plant Biol. 2020, 63, 117-130. [CrossRef]

86. Liu, J.; Ishitani, M.; Halfter, U.; Kim, C.S.; Zhu, J.K. The Arabidopsis thaliana SOS2 gene encodes a protein kinase that is required for salt tolerance. Proc. Natl. Acad Sci. USA 2000, 97, 3730-3734. [CrossRef]

87. Liu, J.; Zhu, J.-K. A calcium sensor homolog required for plant salt tolerance. Science 1998, 280, 1943-1945. [CrossRef]

88. Wang, Y.; Li, T.; John, S.J.; Chen, M.; Chang, J.; Yang, G.; He, G. A CBL-interacting protein kinase TaCIPK27 confers drought tolerance and exogenous ABA sensitivity in transgenic Arabidopsis. Plant Physiol. Biochem. 2018, 123, 103-113. [CrossRef]

89. Cui, X.-Y.; Du, Y.-T.; Fu, J.-D.; Yu, T.-F.; Wang, C.-T.; Chen, M.; Chen, J.; Ma, Y.-Z.; Xu, Z.-S. Wheat CBL-interacting protein kinase 23 positively regulates drought stress and ABA responses. BMC Plant Biol. 2018, 18, 93. [CrossRef]

90. Kim, K.-N.; Cheong, Y.H.; Grant, J.J.; Pandey, G.K.; Luan, S. CIPK3, a calcium sensor-associated protein kinase that regulates abscisic acid and cold signal transduction in Arabidopsis. Plant Cell 2003, 15, 411-423. [CrossRef]

91. Li, T.; Wu, X.-Y.; Li, H.; Song, J.-H.; Liu, J.-Y. A dual-function transcription factor, AtYY1, is a novel negative regulator of the Arabidopsis aba response network. Mol. Plant 2016, 9, 650-661. [CrossRef]

92. Sanyal, S.K.; Kanwar, P.; Yadav, A.K.; Sharma, C.; Kumar, A.; Pandey, G.K. Arabidopsis CBL interacting protein kinase 3 interacts with ABR1, an APETALA2 domain transcription factor, to regulate ABA responses. Plant Sci. 2017, 254, 48-59. [CrossRef]

93. Sun, Z.; Qi, X.; Li, P.; Wu, C.; Zhao, Y.; Zhang, H.; Wang, Z. Overexpression of aThellungiella halophila CB19 homolog, ThCBL9, confers salt and osmotic tolerances in transgenicarabidopsis thaliana. J. Plant Biol. 2008, 51, 25-34. [CrossRef]

94. Ogunrinde, A.; Munro, K.; Davidson, A.; Ubaid, M.; Snedden, W.A. Arabidopsis calmodulin-like proteins, CML15 and CML16 possess biochemical properties distinct from calmodulin and show non-overlapping tissue expression patterns. Front. Plant Sci. 2017, 8, 2175. [CrossRef] [PubMed] 
95. Zhang, K.; Yue, D.; Wei, W.; Hu, Y.; Feng, J.; Zou, Z. Characterization and functional analysis of calmodulin and calmodulin-like genes in fragaria vesca. Front. Plant Sci. 2016, 7, 1820. [CrossRef]

96. Zhang, Q.; Liu, X.; Liu, X.; Wang, J.; Yu, J.; Hu, D.; Hao, Y. Genome-wide identification, characterization, and expression analysis of calmodulin-like proteins (CMLs) in apple. Hortic. Plant J. 2017, 3, 219-231. [CrossRef]

97. Wu, X.; Qiao, Z.; Liu, H.; Acharya, B.R.; Li, C.; Zhang, W. CML20, an Arabidopsis calmodulin-like protein, negatively regulates guard cell ABA signaling and drought stress tolerance. Front. Plant Sci. 2017, 8, 824. [CrossRef]

98. McCormack, E.; Tsai, Y.-C.; Braam, J. Handling calcium signaling: Arabidopsis CaMs and CMLs. Trends Plant Sci. 2005, 10, 383-389. [CrossRef]

99. Li, C.; Meng, D.; Zhang, J.; Cheng, L. Genome-wide identification and expression analysis of calmodulin and calmodulin-like genes in apple (Malusxdomestica). Plant Physiol. Biochem. 2019, 139, 600-612. [CrossRef] [PubMed]

100. Jain, M.; Nagar, P.; Goel, P.; Singh, A.K.; Kumari, S.; Mustafiz, A. Second messengers: Central regulators in plant abiotic stress response. In Abiotic Stress-Mediated Sensing and Signaling in Plants: An Omics Perspective; Springer: Singapore, 2018 ; pp. 47-94.

101. Yoo, J.H.; Park, C.Y.; Kim, J.C.; Heo, W.D.; Cheong, M.S.; Park, H.C.; Kim, M.C.; Moon, B.C.; Choi, M.S.; Kang, Y.H.; et al. Direct interaction of a divergent CaM isoform and the transcription factor, MYB2, enhances salt tolerance in Arabidopsis. J. Biol. Chem. 2005, 280, 3697-3706. [CrossRef]

102. Doherty, C.J.; Van Buskirk, H.A.; Myers, S.J.; Thomashow, M.F. Roles for Arabidopsis CAMTA transcription factors in coldregulated gene expression and freezing tolerance. Plant Cell 2009, 21, 972-984. [CrossRef] [PubMed]

103. Kidokoro, S.; Yoneda, K.; Takasaki, H.; Takahashi, F.; Shinozaki, K.; Yamaguchi-Shinozaki, K. Different cold-signaling pathways function in the responses to rapid and gradual decreases in temperature. Plant Cell 2017, 29, 760-774. [CrossRef]

104. Ramirez, V.E.; Poppenberger, B. MAP kinase signaling turns to ICE. Dev. Cell 2017, 43, 545-546. [CrossRef]

105. Yang, T.; Ali, G.S.; Yang, L.; Du, L.; Reddy, A.S.; Poovaiah, B.W. Calcium/calmodulin-regulated receptor-like kinase CRLK1 interacts with MEKK1 in plants. Plant Signal. Behav. 2010, 5, 991-994. [CrossRef]

106. Townley, H.E.; Knight, M.R. Calmodulin as a potential negative regulator of Arabidopsis COR gene expression. Plant Physiol. 2002, 128, 1169-1172. [CrossRef]

107. Yang, S.-H.; Sharrocks, A.D.; Whitmarsh, A. MAP kinase signalling cascades and transcriptional regulation. Gene 2013, 513, 1-13. [CrossRef]

108. Li, H.; Ding, Y.; Shi, Y.; Zhang, X.; Zhang, S.; Gong, Z.; Yang, S. MPK3- and MPK6-mediated ICE1 phosphorylation negatively regulates ICE1 stability and freezing tolerance in Arabidopsis. Dev. Cell 2017, 43, 630-642.e4. [CrossRef]

109. Zhao, C.; Wang, P.; Si, T.; Hsu, C.-C.; Wang, L.; Zayed, O.; Yu, Z.; Zhu, Y.; Dong, J.; Tao, W.A.; et al. MAP kinase cascades regulate the cold response by modulating ICE1 protein stability. Dev. Cell 2017, 43, 618-629.e5. [CrossRef] [PubMed]

110. Danquah, A.; de Zelicourt, A.; Boudsocq, M.; Neubauer, J.; Frey, N.F.D.; Leonhardt, N.; Pateyron, S.; Gwinner, F.; Tamby, J.-P.; Ortiz-Masia, M.D.; et al. Identification and characterization of an ABA-activated MAP kinase cascade in Arabidopsis thaliana. Plant J. 2015, 82, 232-244. [CrossRef] [PubMed]

111. Takahashi, Y.; Zhang, J.; Hsu, P.-K.; Ceciliato, P.H.O.; Zhang, L.; Dubeaux, G.; Munemasa, S.; Ge, C.; Zhao, Y.; Hauser, F.; et al. MAP3Kinase-dependent SnRK2-kinase activation is required for abscisic acid signal transduction and rapid osmotic stress response. Nat. Commun. 2020, 11, 12. [CrossRef] [PubMed]

112. Yang, L.; Jin, Y.; Huang, W.; Sun, Q.; Liu, F.; Huang, X. Full-length transcriptome sequences of ephemeral plant Arabidopsis pumila provides insight into gene expression dynamics during continuous salt stress. BMC Genom. 2018, 19, 717. [CrossRef]

113. Mitula, F.; Tajdel, M.; Cieśla, A.; Kasprowicz-Maluśki, A.; Kulik, A.; Babula-Skowronska, D.; Michalak, M.; Dobrowolska, G.; Sadowski, J.; Ludwików, A. Arabidopsis ABA-activated kinase MAPKKK18 is regulated by protein phosphatase 2C ABI1 and the ubiquitin-proteasome pathway. Plant Cell Physiol. 2015, 56, 2351-2367. [CrossRef] [PubMed]

114. Azarkovich, M.I. Dehydrins in orthodox and recalcitrant seeds. Russ. J. Plant Physiol. 2020, 67, 221-230. [CrossRef]

115. Bojórquez-Velázquez, E.; Barrera-Pacheco, A.; Espitia-Rangel, E.; Herrera-Estrella, A.; De La Rosa, A.P.B. Protein analysis reveals differential accumulation of late embryogenesis abundant and storage proteins in seeds of wild and cultivated amaranth species. BMC Plant Biol. 2019, 19, 59. [CrossRef] [PubMed]

116. Kalemba, E.M.; Litkowiec, M. Functional characterization of a dehydrin protein from Fagus sylvatica seeds using experimental and in silico approaches. Plant Physiol. Biochem. 2015, 97, 246-254. [CrossRef]

117. Eriksson, S.K.; Kutzer, M.; Procek, J.; Gröbner, G.; Harryson, P. Tunable membrane binding of the intrinsically disordered dehydrin Lti30, a cold-induced plant stress protein. Plant Cell 2011, 23, 2391-2404. [CrossRef]

118. Feng, Z.-J.; Xu, S.-C.; Liu, N.; Zhang, G.-W.; Hu, Q.-Z.; Xu, Z.-S.; Gong, Y.-M. Identification of the AQP members involved in abiotic stress responses from Arabidopsis. Gene 2018, 646, 64-73. [CrossRef]

119. Xu, Y.; Hu, W.; Liu, J.; Song, S.; Hou, X.; Jia, C.; Li, J.; Miao, H.; Wang, Z.; Tie, W.; et al. An aquaporin gene MaPIP2-7 is involved in tolerance to drought, cold and salt stresses in transgenic banana (Musa acuminata L.). Plant Physiol. Biochem. 2020, 147, 66-76. [CrossRef] [PubMed]

120. Li, X.; Liu, Q.; Feng, H.; Deng, J.; Zhang, R.; Wen, J.; Dong, J.; Wang, T. Dehydrin MtCAS31 promotes autophagic degradation under drought stress. Autophagy 2020, 16, 862-877. [CrossRef]

121. Nguyen, P.N.; Tossounian, M.-A.; Kovacs, D.S.; Thu, T.T.; Stijlemans, B.; Vertommen, D.; Pauwels, J.; Gevaert, K.; Angenon, G.; Messens, J.; et al. Dehydrin ERD14 activates glutathione transferase Phi9 in Arabidopsis thaliana under osmotic stress. Biochim. Biophys. Acta Gen. Subj. 2020, 1864, 129506. [CrossRef] [PubMed] 
122. Hara, M.; Monna, S.; Murata, T.; Nakano, T.; Amano, S.; Nachbar, M.; Wätzig, H. The Arabidopsis KS-type dehydrin recovers lactate dehydrogenase activity inhibited by copper with the contribution of His residues. Plant Sci. 2016, 245, 135-142. [CrossRef] [PubMed]

123. Ohkubo, T.; Kameyama, A.; Kamiya, K.; Kondo, M.; Hara, M. F-segments of Arabidopsis dehydrins show cryoprotective activities for lactate dehydrogenase depending on the hydrophobic residues. Phytochemistry 2020, 173, 112300. [CrossRef] [PubMed]

124. Yang, Z.; Sheng, J.; Lv, K.; Ren, L.; Zhang, D. Y2SK2 and SK3 type dehydrins from Agapanthus praecox can improve plant stress tolerance and act as multifunctional protectants. Plant Sci. 2019, 284, 143-160. [CrossRef]

125. Kumar, M.; Lee, S.-C.; Kim, J.-Y.; Kim, S.-J.; Aye, S.S.; Kim, S.-R. Over-expression of dehydrin gene, OsDhn1, improves drought and salt stress tolerance through scavenging of reactive oxygen species in rice (Oryza sativa L.). J. Plant Biol. 2014, 57, 383-393. [CrossRef]

126. Saibi, W.; Feki, K.; Ben Mahmoud, R.; Brini, F. Durum wheat dehydrin (DHN-5) confers salinity tolerance to transgenic Arabidopsis plants through the regulation of proline metabolism and ROS scavenging system. Planta 2015, 242, 1187-1194. [CrossRef]

127. Boddington, K.F.; Graether, S.P. Binding of a Vitis riparia dehydrin to DNA. Plant Sci. 2019, 287, 110172. [CrossRef]

128. Kim, S.Y.; Nam, K.H. Physiological roles of ERD10 in abiotic stresses and seed germination of Arabidopsis. Plant Cell Rep. 2010, 29, 203-209. [CrossRef]

129. Kovacs, D.; Kalmár, É.; Torok, Z.; Tompa, P. Chaperone activity of ERD10 and ERD14, two disordered stress-related plant proteins. Plant Physiol. 2008, 147, 381-390. [CrossRef]

130. Zhang, D.; Yang, T.; Ren, L. Y2SK2- and SK3-type dehydrins from Agapanthus praecox act as protectants to improve plant cell viability during cryopreservation. Plant Cell Tissue Organ Cult. 2021, 144, 271-279. [CrossRef]

131. Meng, Y.-C.; Zhang, H.-F.; Pan, X.-X.; Chen, N.; Hu, H.-F.; Haq, S.; Khan, A.; Chen, R.-G. CaDHN3, a pepper (Capsicum annuum L.) dehydrin gene enhances the tolerance against salt and drought stresses by reducing ROS accumulation. Int. J. Mol. Sci. 2021, 22, 3205. [CrossRef]

132. Shin, S.-Y.; Kim, H.-Y.; Kim, I.-S.; Kim, J.-J.; Kim, Y.-S.; Yoon, H.-S. The dehydrin gene of the Arctic plant Cerastium arcticum, CaDHN, increases tolerance to multiple stresses in Arabidopsis thaliana. Plant Biotechnol. Rep. 2020, 14, 387-395. [CrossRef]

133. Poku, S.A.; Chukwurah, P.N.; Aung, H.H.; Nakamura, I. Over-expression of a melon Y3SK2-Type LEA gene confers drought and salt tolerance in transgenic tobacco plants. Plants 2020, 9, 1749. [CrossRef]

134. Zhou, Y.; He, P.; Xu, Y.; Liu, Q.; Yang, Y.; Liu, S. Overexpression of CsLEA11, a Y3SK2-type dehydrin gene from cucumber (Cucumis sativus), enhances tolerance to heat and cold in Escherichia coli. AMB Express 2017, 7, 182. [CrossRef] [PubMed]

135. Zhang, H.; Zheng, J.; Su, H.; Xia, K.; Jian, S.; Zhang, M. Molecular cloning and functional characterization of the dehydrin (IpDHN) gene from ipomoea pes-caprae. Front. Plant Sci. 2018, 9, 1454. [CrossRef] [PubMed]

136. Ju, H.; Li, D.; Li, D.; Yang, X.; Liu, Y. Overexpression of ZmDHN11 could enhance transgenic yeast and tobacco tolerance to osmotic stress. Plant Cell Rep. 2021, 40, 1723-1733. [CrossRef]

137. Koag, M.-C.; Wilkens, S.; Fenton, R.D.; Resnik, J.; Vo, E.; Close, T.J. The K-segment of maize DHN1 mediates binding to anionic phospholipid vesicles and concomitant structural changes. Plant Physiol. 2009, 150, 1503-1514. [CrossRef]

138. Xie, C.; Zhang, R.; Qu, Y.; Miao, Z.; Zhang, Y.; Shen, X.; Wang, T.; Dong, J. Overexpression of MtCAS31 enhances drought tolerance in transgenic Arabidopsis by reducing stomatal density. New Phytol. 2012, 195, 124-135. [CrossRef] [PubMed]

139. Guo, X.; Zhang, L.; Wang, X.; Zhang, M.; Xi, Y.; Wang, A.; Zhu, J. Overexpression of Saussurea involucrata dehydrin gene SiDHN promotes cold and drought tolerance in transgenic tomato plants. PLoS ONE 2019, 14, e0225090. [CrossRef]

140. Danyluk, J.; Perron, A.; Houde, M.; Limin, A.; Fowler, B.; Benhamou, N.; Sarhan, F. Accumulation of an acidic dehydrin in the vicinity of the plasma membrane during cold acclimation of wheat. Plant Cell 1998, 10, 623-638. [CrossRef]

141. Drira, M.; Saibi, W.; Brini, F.; Gargouri, A.; Masmoudi, K.; Hanin, M. The K-segments of the wheat dehydrin DHN-5 are essential for the protection of lactate dehydrogenase and beta-glucosidase activities in vitro. Mol. Biotechnol. 2013, 54, 643-650. [CrossRef] 